\title{
RANCANG BANGUN APLIKASI PENJADWALAN HOME SERVICE INDORENT MENGGUNAKAN ALGORITMA FIRST COME FIRST SERVED BERBASIS ANDORID
}

\author{
Agung Prasetiya \\ Jurusan Teknik Informatika, Fakultas IImu Komputer, Universitas Mercu Buana \\ Jakarta, telp/fax of institution/affiliation, e-mail: 41516110018@student.mercubuana.ac.id
}

\section{ARTICLE INFO}

Article history:

Received 30 December 2010

Received in revised form 30 April 2011

Accepted 26 September 2012

Available online 8 October 2012

\begin{abstract}
Android smartphone is one of the items that really help humans in living life today. A person gets information through an internet connection using an Android smartphone whenever and wherever he is. Home Services is a vehicle repair service on site. Thus, customers still get service without leaving activity. The Home Service System is still manual so that it gives customers the opportunity to find out about ordering and scheduling vehicle services. Therefore, the researchers tried to build an Androidbased Home Service application using the First Come First Served algorithm to facilitate scheduling. Analytical methods conducted by researchers by collecting data through Literature Studies and Interviews. Thus, resulting in an easier, practical, simple, and efficient Home Services application where customers can schedule vehicle services via an Android Smartphone.
\end{abstract}

Keywords: Home Service, First Come First Served, Android, Java

\section{Pendahuluan \\ Di zaman Milenial ini seiring berjalannya waktu, teknologi pun tumbuh dengan cepat dan canggih Smartphone Android adalah salah satu barang yang sangat membantu manusia dalam menjalani kehidupan dimasa sekarang. Seseorang mendapatkan informasi melalui koneksi internet dengan menggunakan Smartphone Android kapanpun dan dimanapun dia berada. Penerapan yang sangat fleksibel inilah yang dibutuhkan oleh pelanggan Indorent, mereka bisa booking dan menjadwalkan Home Service untuk memperbaiki dan perawatan rutin kendaraan mobil. Home Service merupakan salah satu bentuk layanan yang diberikan oleh setiap bengkel mobil terutama di PT. CSM Corporatama dalam meningkatkan pelayanan kepada pelanggannya. Padatnya penjadwalan Home Service dalam memperbaiki kendaraan mobil customer membuat Home Service tidak efisien waktu dan seringkali bentrok dengan penjadwalkan customer satu dengan customer lainnya mengakibatkan penjadwalan tidak teratur}

Dari permasalahan diatas, penulis ingin membuat suatu aplikasi yang dapat digunakan dengan mudah diakses dan dengan memanfaatkan teknologi yang ada seperti aplikasi mobile yang terdapat pada salah satu referensi penulis yaitu Auto200Mobile. Sehingga, memudahkan pelanggan untuk service kendaraan mobil terutama home service dan akan menghasilkan penjadwalan yang lebih efisien dengan algoritma first come first served. Algoritma First Come First Served sebagai metode penjadwalan yang paling sederhana. Dengan menggunakan algoritma ini setiap proses yang berada pada status ready dimasukkan kedalam antrian. Sehingga, tidak ditemukan bentrok pada saat booking atau daftar home service kendaraan mobil. 


\section{Penelitian Terkait}

Dari hasil studi pustaka, ditemukan perbandingan penelitian sejenis terdahulu dengan penelitian yang dilakukan penelitian dapat dirangkum dalam bentuk table yang dapat dilihat pada Tabel 1.

Tabel. 1 Penelitian Terkait

\begin{tabular}{|c|c|c|c|c|}
\hline Penelitian & Judul & Persamaan & Perbedaan & Hasil Penelitian \\
\hline $\begin{array}{l}\text { Rosalia Hadi, } \\
\text { Yohana } \\
\text { Nugrahaeni } \\
\text { (2016) [1]. }\end{array}$ & $\begin{array}{l}\text { Aplikasi } \\
\text { Penjadwalan } \\
\text { Terapi dengan } \\
\text { Metode FCFS } \\
\text { padar Sixo } \\
\text { Reflexology. }\end{array}$ & $\begin{array}{l}\text { Memberikan } \\
\text { kemudahan } \\
\text { dalam } \\
\text { penjadawlan } \\
\text { Terapi pada Sixo } \\
\text { Reflexology. }\end{array}$ & $\begin{array}{l}\text { Aplikasi masih } \\
\text { berbasis website. }\end{array}$ & $\begin{array}{l}\text { Menghasilkan } \\
\text { system informasi } \\
\text { penjadwalan } \\
\text { pendaftaran } \\
\text { (pengambilan } \\
\text { antrain) serta } \\
\text { penyajian } \\
\text { laporan dan } \\
\text { informasi. }\end{array}$ \\
\hline $\begin{array}{l}\text { Taronisokhi } \\
\text { Zebua,Syukur } \\
\text { Novertiani Gulo } \\
\text { Surya Darma } \\
\text { Nasution, } \\
\text { Guidio } \\
\text { Leonarde } \\
\text { Ginting4 (2016) } \\
\text { [2]. }\end{array}$ & $\begin{array}{l}\text { Simulasi Antrian } \\
\text { Pelayanan } \\
\text { Pembagian Dana } \\
\text { Program Simpan } \\
\text { Keluarga } \\
\text { Sejahtera } \\
\text { Menggunakan } \\
\text { Algoritma First } \\
\text { Come r First } \\
\text { Serve. }\end{array}$ & $\begin{array}{l}\text { Membangun } \\
\text { system yang } \\
\text { berguna untuk } \\
\text { antrian } \\
\text { pelayanan } \\
\text { pembagaian } \\
\text { dana yang lebih } \\
\text { akurat dan jelas. }\end{array}$ & $\begin{array}{l}\text { Metode } \\
\text { pengembangan } \\
\text { system yang } \\
\text { digunakan } \\
\text { berbeda. }\end{array}$ & $\begin{array}{l}\text { Algoritma first } \\
\text { come first server } \\
\text { diterapkan pada } \\
\text { simulasi antrian } \\
\text { pelayanan } \\
\text { pembagian dana } \\
\text { program } \\
\text { simpanan } \\
\text { keluarga } \\
\text { sejahtera dengan } \\
\text { cara } \\
\text { mensimulasikan } \\
\text { jumlah rata-rata } \\
\text { Rumah Tangga } \\
\text { Sasaran (RTS) } \\
\text { yang masuk 10, } \\
\text { dan memiliki } 2 \\
\text { server dan } \\
\text { dibutuhkan data } \\
\text { waktu } \\
\text { kedatangan, } \\
\text { waktu mulai } \\
\text { pelayanan, lama } \\
\text { waktu pelayanan } \\
\text { sehingga dapat } \\
\text { waktu disistem } \\
3,17 \text { menit, } \\
\text { waktu rata-rata } \\
\text { RTS menunggu } \\
\text { dalam sistem } \\
\text { selama 0,02 jam } \\
\text { atau 1,2 menit } \\
\text { per orang. }\end{array}$ \\
\hline
\end{tabular}




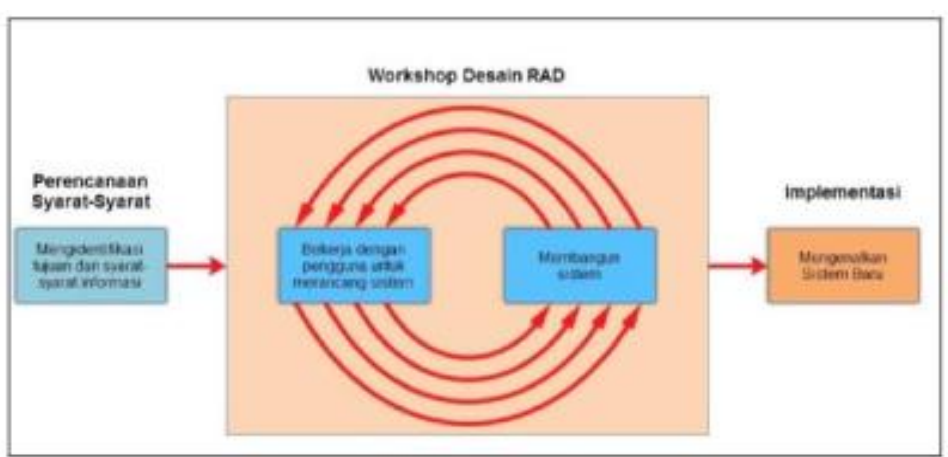

Gambar. 1 Siklus RAD (14)

Model RAD memiliki 3 tahapan sebagai berikut :

1. Rencana Kebutuhan (Requirement Planning) : User dan analyst melakukan pertemuan untuk mengidentifikasi tujuan dari sistem dan kebutuhan informasi untuk mencapai tujuan. Pada tahap ini yaitu hal terpenting yaitu adanya saling keterlibatan dari berbagai kedua belah pihak.

2. RAD Design Workshop (Work Desain RAD) : Tahap ini untuk merancang dan memperbaiki digambarkan sebegai workshop. Penganalisis dan pemrogram dapat bekerja membangun dan representasi visual desain dan pola kerja kepada pengguna. Maka, perlu keaktifan user yang terlibat menentukan untuk mencapai tujuan karena pada proses ini melakukan proses desain dan melakukan perbaikan-perbaikan apabila masih terdapat ketidaksesuaian desain antara user dan analyst.

3. Implementasi (Implementation) : Tahapan yang terakhir bagi seorang programmer yang membangun dan mengembangkan desain suatu program yang telah disetujui oleh user dan analyst. Sebelum terbentuknya aplikasi pada suatu organisasi terlebih dahulu melakukan proses pengujian terhadap program tersebut apakah ada kesalahan atau tidak [14].

\subsection{Algoritma First Come First Served}

Merupakan algoritma penjadwalan dengan karakteristik mengutamakan proses yang di submit terlebih dahulu, yang pertama datang yang pertama dilayani. Maka, proses yang tiba terlebih dahulu yang akan dieksekusi terlebih dahulu. Penjadwalan FCFS adalah penjadwalan dengan ketentuan - ketentuan sederhana, yaitu proses-proses diberi jarak waktu pemroses diurutkan berdasarkan waktu kedatangan proses-proses itu ke system. Saat proses mendapat jatah waktu pemroses, proses dijalankan sampai selesai. Sehingga dapat dikatakan bahwa metode penjadwalan ini adil dalam arti resmi. Penjadwalan algoritma first come first serve berdasarkan rumus sebagai berikut [2].

Contoh, Data Proses dan Burst Time FCFS adalah sebagai berikut : [2]

Tabel. 2 Data Proses dan Burst Time FCFS

\begin{tabular}{|l|l|l|l|}
\hline Proses & Waktu (Burst Time) & Urutan & $\begin{array}{l}\text { Kedatangan (Arrival } \\
\text { Time) }\end{array}$ \\
\hline P1 & 16 & 1 & 0 \\
\hline P2 & 4 & 2 & 0 \\
\hline P3 & 6 & 3 & 0 \\
\hline
\end{tabular}

Waktu tunggu $\mathrm{P} 1=0, \mathrm{P} 1$ berada pada urutan pertama, ia tidak menunggu siapapun untuk memulai, $\mathrm{P} 2=16, \mathrm{P} 2$ menunggu $\mathrm{P} 1$ untuk dapat memulai proses, dan $\mathrm{P} 3=20$ karena $\mathrm{P} 3$ menunggu P2 selesai proses. Dan berapa rata-rata waktu tunggu untuk semua proses? Jawabannya adalah $(0+16+20)=12[2]$. 


\section{Hasil dan Analysis}

\subsection{Analysis}

Peneliti melakukan analisi masalah metode yang dilakukan adalah metode Performance, Information, Economics, Control, Eficiency dan Service yang disingkat PIECES pada table berikut ini : [16]

Tabel 3. Analisa PIECES

\begin{tabular}{|c|c|c|}
\hline Kerangka PIECES & Sistem Lama & Solusi \\
\hline Performance (Kinerja) & $\begin{array}{l}\text { Relatif lebih lamban dalam } \\
\text { mengelola pemesanan booking } \\
\text { service karena } r \text { proses } \\
\text { pemesanan harus dilakukan } \\
\text { via email atau bertemu } \\
\text { langsung kepada } \\
\text { bengkel }\end{array}$ & $\begin{array}{l}\text { Menyediakan sebuah aplikasi } \\
\text { yang menyediakan fitur } \\
\text { pemesanan booking service }\end{array}$ \\
\hline Information (Informasi) & $\begin{array}{llr}\text { Informasi } & \text { terkait } & \text { proses } \\
\text { pemesanan } & \text { booking } & \text { service } \\
\text { yang tidak } & \text { akurat mengenai } \\
\text { penjadwalan booking service }\end{array}$ & $\begin{array}{l}\text { Menyediakan sebuah aplikasi } \\
\text { yang dapat memberikan } \\
\text { informasi terkait penjadwalan } \\
\text { booking service }\end{array}$ \\
\hline Economics (Ekonomi) & $\begin{array}{l}\text { Biaya yang harus dikeluarkan } \\
\text { relatif banyak dikarenakan } \\
\text { user harus datang ke tempat } \\
\text { service }\end{array}$ & $\begin{array}{l}\text { Meyediakan sebuah aplikasi } \\
\text { yang dapat memberikan } \\
\text { informasi penjadwalan service } \\
\text { booking serta user terperlu } \\
\text { harus dating ke bengkel }\end{array}$ \\
\hline Control (Pengendalian) & $\begin{array}{l}\text { Pada pemrosesan pemesanan } \\
\text { booking service sering terjadi } \\
\text { kesalahan atau error }\end{array}$ & $\begin{array}{l}\text { Perlunya ada sebuah aplikasi } \\
\text { yang dapat memonitor status } \\
\text { pem-rosesan pemesanan } \\
\text { booking service }\end{array}$ \\
\hline Eficiency (Efisiensi) & $\begin{array}{l}\text { Banyak menghabiskan waktu } \\
\text { dalam proses pencarian jadwal } \\
\text { booking }\end{array}$ & $\begin{array}{l}\text { Menyediakan sebuah aplikasi } \\
\text { yang dapat membuat efesiensi } \\
\text { dalam proses pencarian jadwal } \\
\text { booking service }\end{array}$ \\
\hline Service (Pelayanan) & $\begin{array}{l}\text { Pada proses pemesanan tidak } \\
\text { bisa dilikukan secara real time }\end{array}$ & $\begin{array}{l}\text { Meyediakan sebuah aplikasi } \\
\text { yang dapat digunakan usesr } \\
\text { untuk melakukan booking } \\
\text { service secara online }\end{array}$ \\
\hline
\end{tabular}

\subsection{Hasil}

\section{a. User Case Diagram}

Berikut ini adalah use case diagram yang menjelaskan fitur-fitur apa saja yang bisa diakses oleh user untuk penggunaan aplikasi Home Service pada Gambar di bawah ini. 


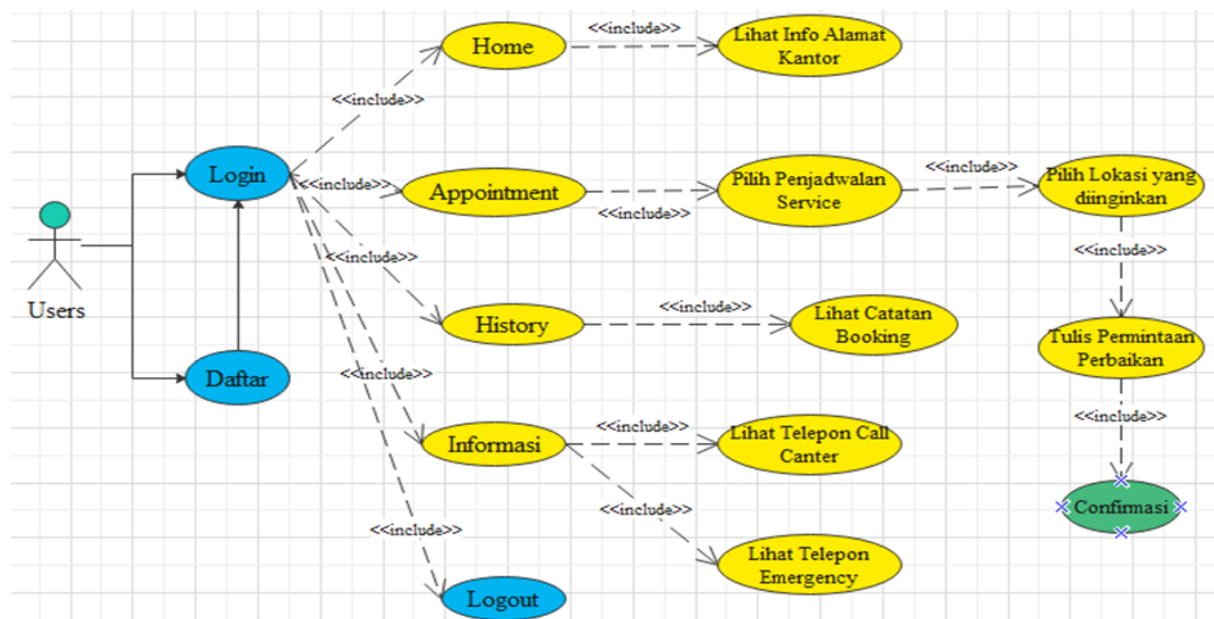

Gambar. 2 Use Case Diagram

\section{b. Activity Diagram}

Berikut ini adalah Gambar alur atau proses kerja yang terjadi dalam aktivitas pemesanan booking service yang dilakukan oleh customer pada gambar di bawah ini.

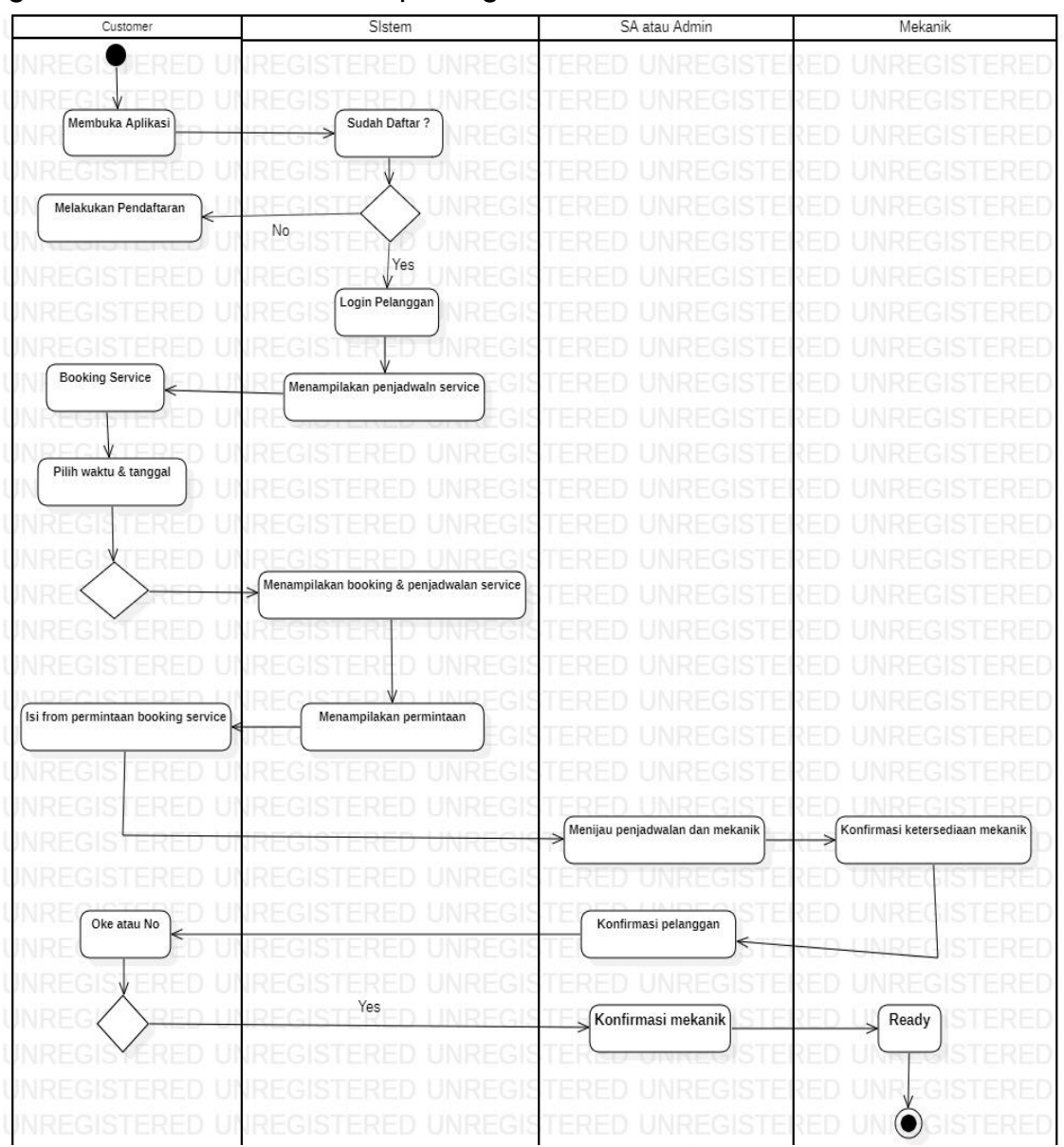

Gambar. 3 Activity Diagram 


\section{c. Class Diagram}

Berikut ini adalah Gambar alur atau proses kerja yang terjadi dalam aktivitas pemesanan booking service yang dilakukan oleh customer pada gambar di bawah ini

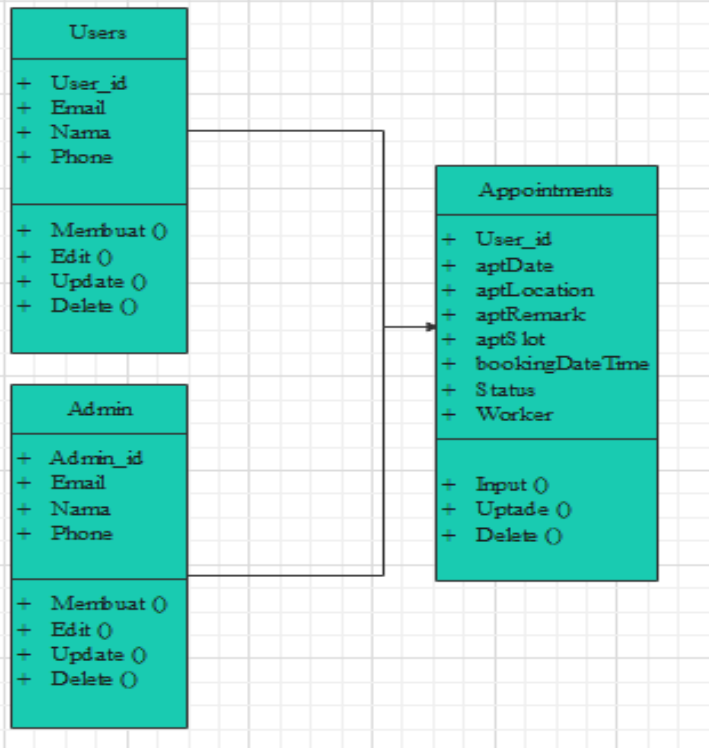

Gambar. 4 Class Diagram

\section{d. Aplikasi GUI}

Hasil dari penelitian ini adalah transaksi aplikasi Home Service penjadwalan booking service kendaraan, sedangkan hasil aplikasi seperti ini :
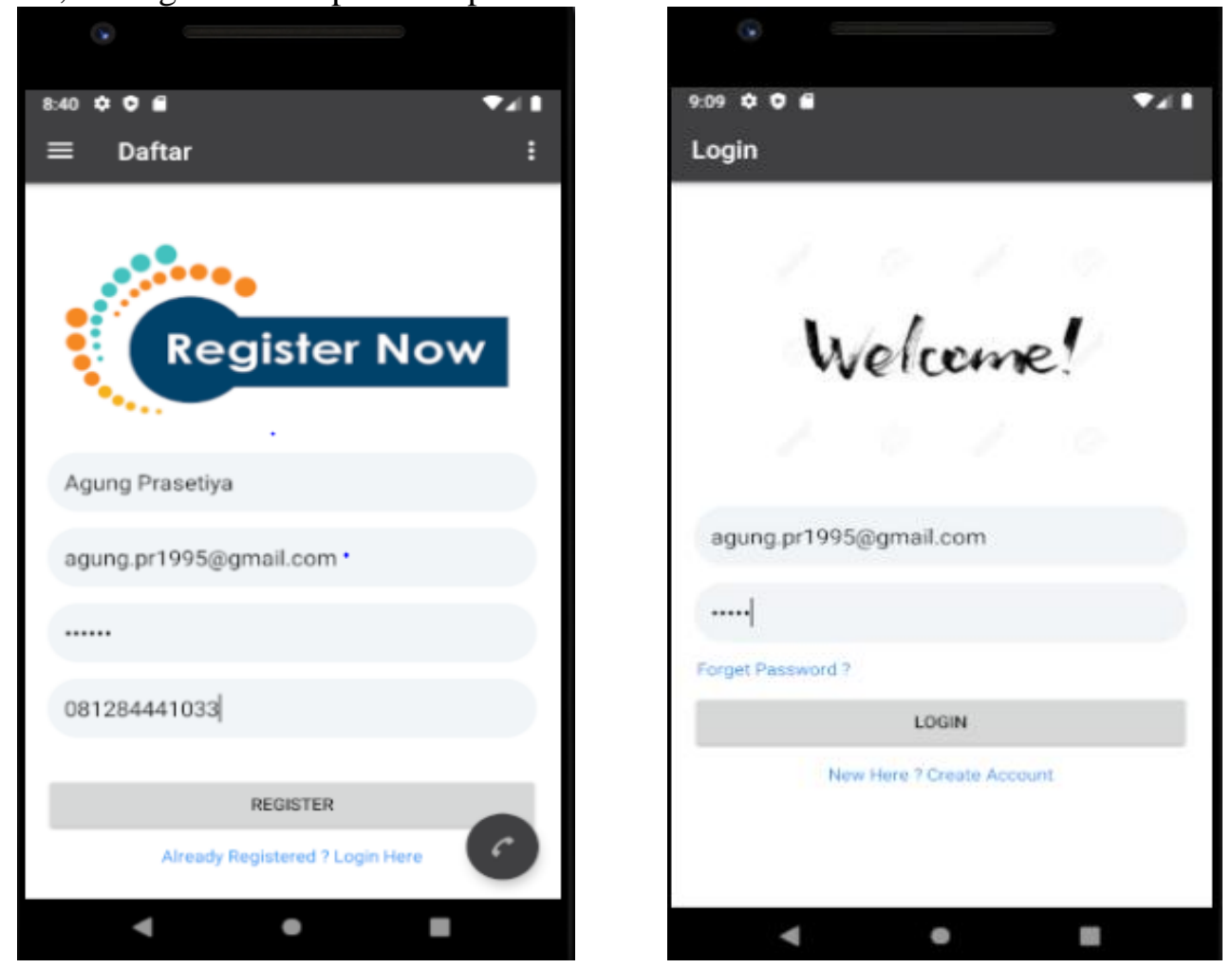

Gambar. 5 Login dan Daftar Users

TRANSFORMATIKA Vol. 18, No. 2, January 2021: 173-181 
Pada gambar nomor 5 halaman Login adalah halaman pertama yang akan pelanggan lihat ketika ingin masuk ke aplikasi Home Service, saat login terlebih dahulu anda harus memasukkan email dan password yang telah terdaftar. Kemudian halaman Daftar adalah halaman kedua yang akan pelanggan lihat jika pelanggan belum mempunya akun. Maka, pelanggan di anjurkan untuk terlebih dahulu daftar.

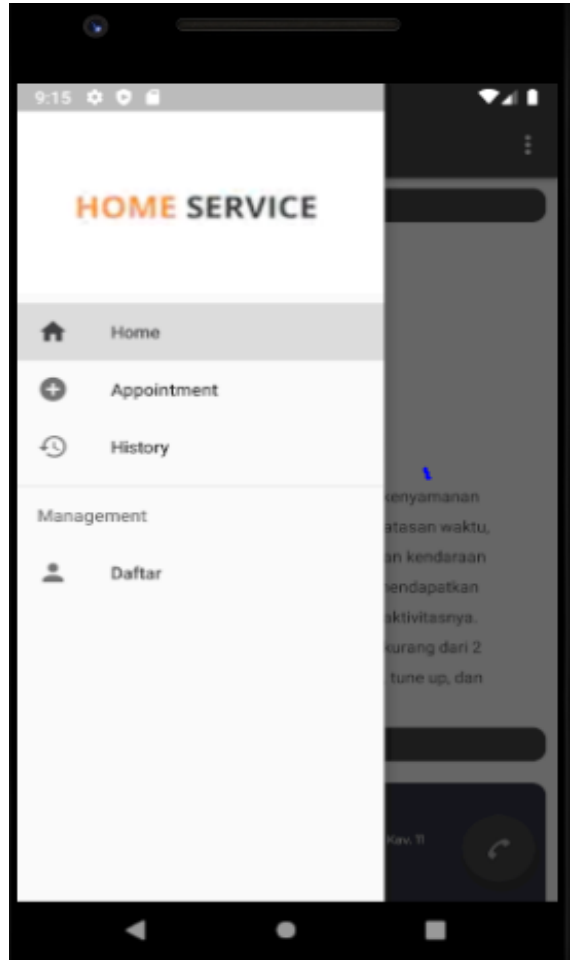

Gambar. 6 Menu

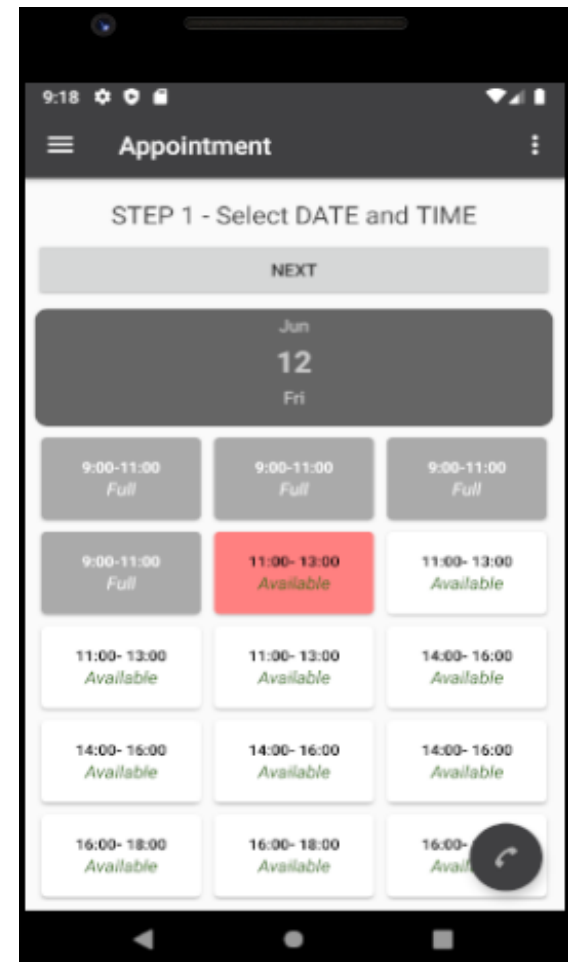

Gambar. 7 Menu Appointment

Halaman menu pada gambar nomor 6 halaman menu adalah menampilkan menu-menu yang ada di aplikasi. Kemudian, pada gambar nomor 7 halaman Appointment adalah dimana menu ini memudahkan user untuk memilih jadwal yang diinginkan user tersebut.

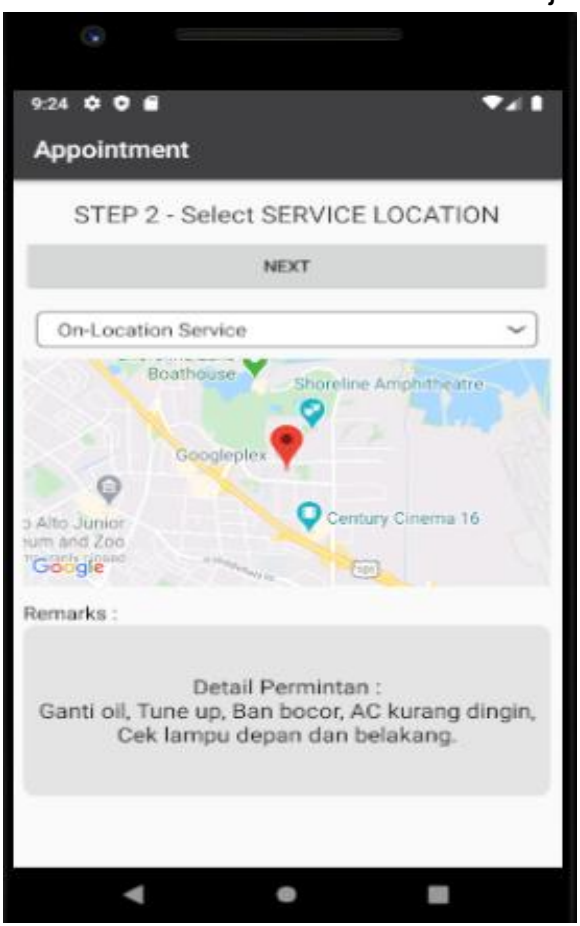

Gambar. 8 Pilih lokasi dan permintaan

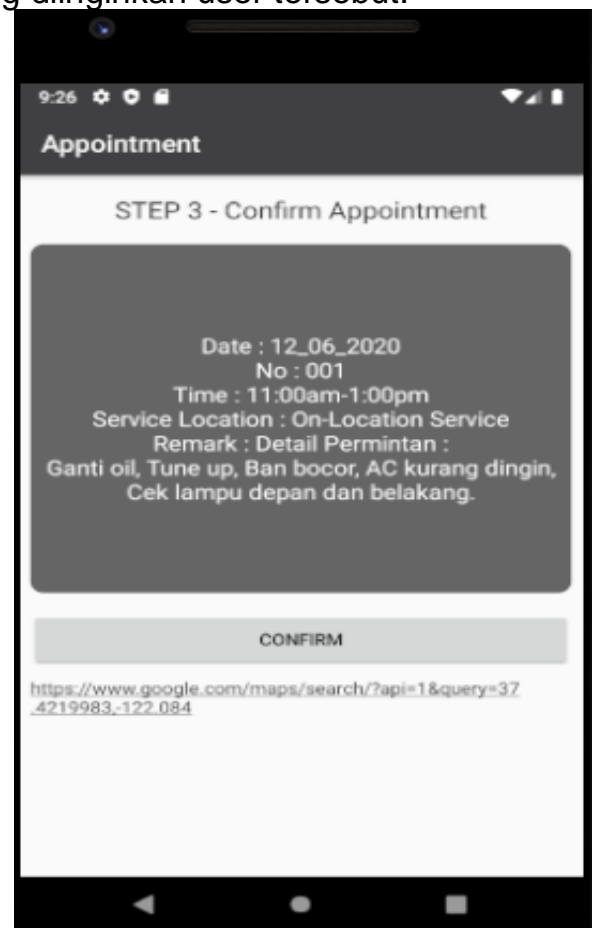

Gambar. 9 Confirm pemesanan booking

Rancang Bangun Aplikasi Penjadwalan Home Service Indorent Menggunakan Algoritma First Come First Served Berbasis Android (Agung Prasetiya) 
Pada gambar nomor 8 di atas menampilkan menu GPS adalah menu gps ini berfungsi untuk user. Ketika, user booking service tidak bisa datang ke workshop user bisa memiliki lokasi dimana user berada. Sehingga, memudahkan user untuk melakukan service kendaraan tersebut. Pada gambar nomor 9 di atas menampilkan menu Confirm adalah menu ini berisi menampilkan keterangan yang sudah user isi data tersebut. Dibawah ini adalah tampilan admin yang memproses data pada user.
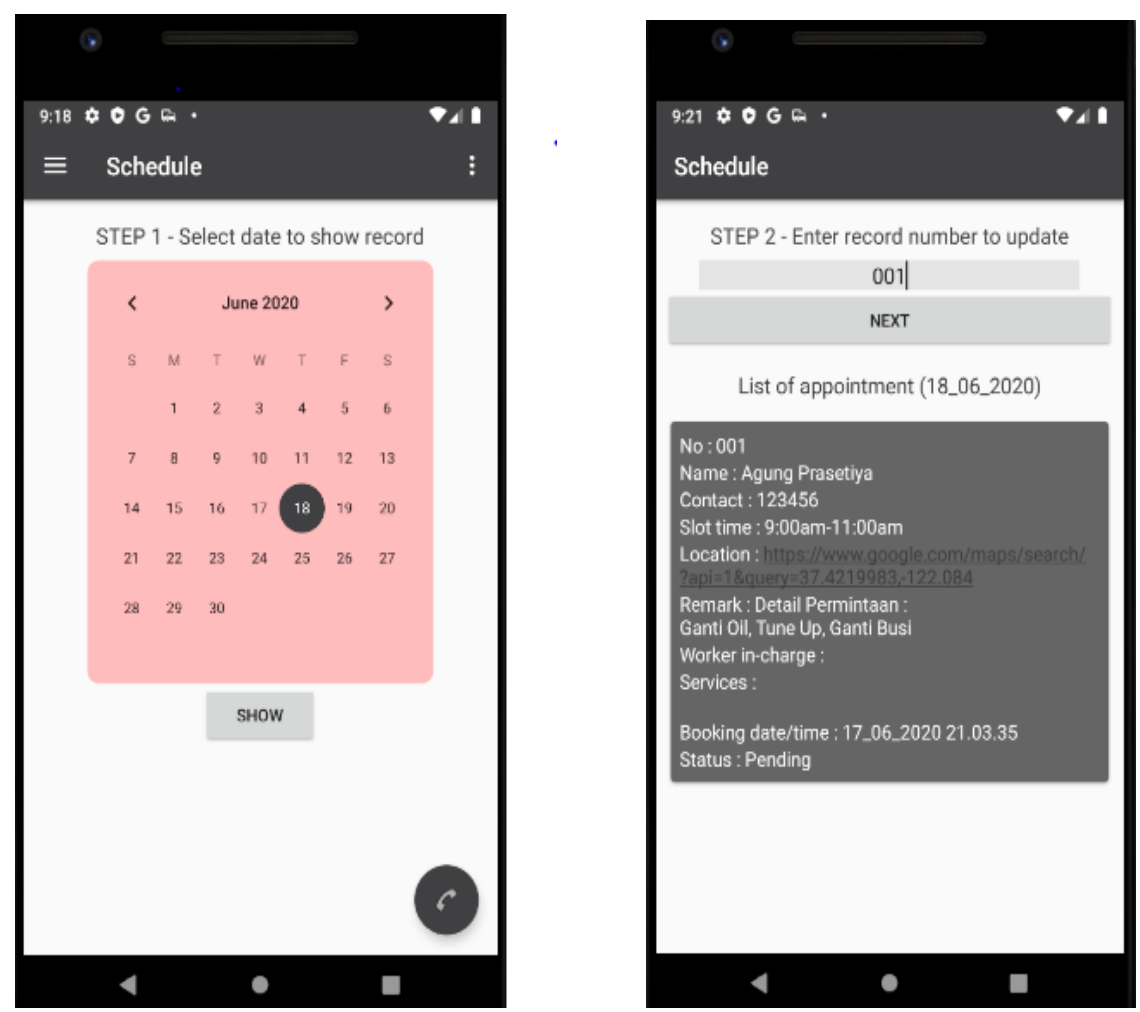

Gambar. 10 Menu Schedulu

Pada gambar nomor 10 Menu Schedule adalah menu ini menampilkan tanggal agar admin bisa melihat Schedule yang user booking service. Dan melakukan pengcekan pada data serta melakukan konfirmasi. Hasil pengujian adalah dokumen yang berisi penjelasan tentang hasil yang diperlukan saat menguji aplikasi home service. Hasil tes dapat dilihat pada tabel. 3

Tabel 3. Hasil Pengujian

\begin{tabular}{|c|c|c|c|c|}
\hline No & Deskripsi & Kondisi Pertama & Test & Hasil \\
\hline 1. & Login Halaman & $\begin{array}{l}\text { Membuka Aplikasi Home } \\
\text { Service }\end{array}$ & Tampil dashboard menu Log in & Success \\
\hline 2. & $\begin{array}{l}\text { Pengujian Sign } \\
U p\end{array}$ & Membuka Akun & $\begin{array}{l}\text { Data Sign } U p \text { telah tersimpan di } \\
\text { Firebase }\end{array}$ & \\
\hline 3. & $\begin{array}{l}\text { Pengujian } \\
\text { Menu pilih } \\
\text { waku }\end{array}$ & lan memilih waktu & $\begin{array}{l}\text { npilkan waktu dan tanggal } \\
\text { kan di pilih }\end{array}$ & Suc \\
\hline 4. & $\begin{array}{l}\text { Pengujian } \\
\text { Menu Location }\end{array}$ & Mencari lokasi & $\begin{array}{l}\text { Menampilkan Maaps untuk mencari } \\
\text { lokasi }\end{array}$ & Success \\
\hline
\end{tabular}

\section{Kesimpulan}

Sistem penjadawalan home service indorent ini berhasil membuat laporan hasil dari transaksi booking dan penjadwlaan service perhari maupun perbulan. Gunanya memudahakan bagi admin 
membuat laporan. Hasil dari apilkasi home service ini membantu dan memudahkan pelanggan untuk booking dan penjadwalan service kendaraan melalui smartphone android. Untuk pengembangan selanjutnya, user Interface perlu dirubah menjadi yang lebih bagus. Sistem ini perlu dibuat versi iOS, sehingga tidak hanya pengguna android, namun pengguna iOS juga dapat menggunakan aplikasi ini.

\section{References :}

[1] Rosalia Hadi, Yuhana Nugrahaeni,"APLIKASI PENJADWALAN TERAPI DENGAN METODE FCFS PADA SISO REFLEXOLOGY,"Jurnal Of Intelligent System, vol. 1, no. 2, Juni 2016.

[2] Taronisokhi Zebua, Syukur Novertiani Gulo, Surya Darma Nasution, Guidio Leonarde Ginting," SIMULASI ANTRIAN PELAYANAN PEMBAGIAN DANA PROGRAM SIMPANAN KELUARGA SEJAHTERA MENGGUNAKAN ALGORITMA FIRST COME FIRST SERVER (STUDI KASUS : PT. POS INDONESIA (PERSERO) MEDAN)," Jurnal Riset Komputer (JURIKOM), Vol. 3 No. 4, Agustus 2016.

[3] Meta Litasari Sestiayunda, Feri Prasetyo H,"Pengembangan Sistem Informasi Booking Service Motor Honda pada Pt. Pacific Motor II Bekasi Berbasis Web," Jurnal Inkofar, Volume 1 No. 2, Desember 2017.

[4] Satria,"Sistem Informasi Pencatatan Service Kendaraan Toyota Berbasis Web," Jurnal Kilat, Vol. 7 N0. 2, September 2018.

[5] Amnah, Ahmad Soleh, Isnandar Agus,"RANCANG BANGUN APLIKASI PREDIKSI SERVICE BERKALA KENDARAAN PELANGGAN PT. ASTRA INTERNASIONAL DAIHATSU BERBASIS WEB," SEMNAS IIB DARMAJAYA., Bandar Lampung: PT.Astra Internasional Daihastsu, Oktober 2017.

[6] Teguh Widodo,"SISTEM PEMESANAN PENGGUNAAN LAPANGAN FUTSAL DENGAN ALGORITMA FIRST COME FIRST SERVED BERBASIS WEBSITE(Studi Kasus Bardosono Happy Futsal Yogyakarta)," 13 Maret 2018.

[7] Agri Kuswandani,"IMPLEMENTASI METODE FIRST COME FIRST SERVED PADA APLIKASI SELF SERVICE ORDER BERBASIS WEB," 05 April 2019.

[8] Nasrullah Syariful Anam (1310651018), Viktor Wahanggara, S. Kom, M. Kom,"Implementasi Metode FCFS( First Come First Served) Pada Aplikasi Pemesanan Makanan Menggunakan QR Code Berbasis Web service Studi Kasus : Mie Kober Jember,"Jember 2018.

[9] E.Maiyan,"Pemanfaatan Android Dalam Perancangan Aplikasi Kumpulan Doa," J.Ilm., vol. x, no. 1, pp.1-6, 2017.

[10] Suendri,"IMPLEMENTASI DIAGRAM UML (Unified Modelling Language) Pada Perancangan Sistem Informasi Remunerasi Dosen Dengan Database Oracle (Studi Kasus: UIN Sumatera Utara Medan),"J.Ilmu komput. dan inform., vol. 3, no. 1, pp. 1-9, $2018 .$.

[11]Riski Pradana, Bayu Priyambadha, Fajar Pradana ,"Pengembangan Aplikasi Pembelajaran Pemrograman Java yang Atraktif Berbasis Android." Jurnal Pengembangan Teknologi Informasi dan Ilmu Komputer Vol. 2, No. 12, Desember 2018.

[12] Andreas Endrahadi Wijaksono, Henry Novianus Palit, Anita Nathania Purbowo,"Aplikasi "Golek Tukang" untuk Pencarian Jasa Perbaikan Rumah di Daerah Surabaya Berbasis Android," Jurnal Infra, Vol. 7, No. 12019.

[13] Sabar Rudiarto, Hendra Prastiawan, Andryanus Agie Hendriawa,"DESIGN OF BAJAJ TRANSPORTATION RENTAL APPLICATION SYSTEM WITH FIRST COME FIRST SERVED ALGORITHM," International Research Journal of Computer Science (IRJCS)., vol. 5,no. 6. June 2018.

[14]Meidyan Permata Putri, Hendra Effendi,"Implementasi Metode Rapid Application Development Pada Website Service Guide "Waterfall Tour South Sumatera," Jurnal SISFOKOM, Volume 07, Nomor 02, September 2018.

[15] Luffi Aditya Sandy, Rizky Januar ,dan Ridho Rahman Hariadi,"Rancang Bangun Aplikasi Chat pada Platform Android dengan Media Input berupa Canvas dan Shareable Canvas untuk Bekerja Dalam Satu Canvas secara Online,"JURNAL TEKNIK ITS Vol. 6, No. 2 (2017).

[16] Hendra Prastiawan, Indra Ranggadara,"DESIGN AND ANALYSIS ADMINISTRATION APPROVAL ORDER SYSTEM IN PT SYSMEX INDONESIA," International Research Journal of Computer Science (IRJCS) Vol. 5, No. 03 March 2018. 